\title{
Idea solidarności społecznej jako przejaw podstawowych praw czlowieka w myśli Józefa Tischnera
}

Koncepcja praw człowieka na gruncie nauk społecznych wciąż pozostaje otwarta i niekompletna. Wynika to z faktu, iż mająca co do zasady wskazywać na potrzebę ochrony jednostki przed nadużyciami ze strony państwa, innych instytucji i jednostek, w każdym czasie i w każdych okolicznościach, musi charakteryzować się dużą pojemnością i elastycznością. Zagrożeń tej idei jest bowiem tyle, ile istnień ludzkich. Każdego człowieka może dotknąć przejaw nieposzanowania życia, godności, wolności czy któregokolwiek innego przyrodzonego prawa. Ów wielki kwantyfikator „każdego” najdosadniej oddaje powszechność praw człowieka. Co za tym idzie, muszą być one jak ,garnitur szyty na miarę”, w którym każdy będzie się dobrze czuł. Zupełnie czegoś innego bowiem w koncepcji tej szukają ofiary konfliktów zbrojnych, a czegoś innego osoby zaangażowane w walkę o prawa mniejszości seksualnych. I dalej, czegoś innego wymagali od niej strajkujący w latach siedemdziesiątych i osiemdziesiątych robotnicy, prześladowani studenci i społecznicy.

* Dr Przemysław Zientkowski pełni funkcję pełnomocnika Burmistrza Miasta Chojnice ds. Rozwoju i Współpracy Naukowej, współpracuje z Zakładem Filozofii Wychowania i Edukacji Obywatelskiej w Instytucie Pedagogiki Uniwersytetu Kazimierza Wielkiego w Bydgoszczy. Adres: Instytut Pedagogiki UKW, ul. Chodkiewicza 30, 85-064 Bydgoszcz; e-mail: przemysławzientkowski@op.pl. 
Wydawać się może, że w ostatnich latach najpilniejszym zadaniem jest maksymalne sformalizowanie prawne koncepcji praw człowieka, poukładanie i dookreślenie poszczególnych paragrafów tak, aby nie pozostawiać miejsca na wątpliwości i dowolną interpretację ${ }^{1}$. Tym samym wyłączne prawo do zajmowania się tą koncepcją częstokroć uzurpują sobie prawnicy, zapominając, iż idea praw człowieka jest raczej moralnej niźli prawnej natury. Otwiera to szereg możliwości do interpretacji koncepcji nie tylko przez gremia i osoby dążące do formalnoprawnej ochrony prawa człowieka (co jest oczywiście niezwykle istotne), ale również przez środowiska i jednostki, które zajmują się badaniem aspiracji i standardów ogólnoludzkich, zwłaszcza przy użyciu narzędzi intelektualnych, nie tyle dających pewność w zakresie sądowego orzekania, ile raczej pozwalających odkryć nowe horyzonty człowieczeństwa i jego ochrony.

Od czasów oświecenia namysł nad ideą praw człowieka winien być podstawowym zadaniem filozofów. Któż bowiem, jak nie oni, dysponuje tak szerokim spectrum narzędzi pozwalającym definiować i opisywać rzeczywistość, a w niej człowieka i jego stosunek do świata, społeczeństwa, do siebie. Jedną z osób, która doskonale zdawała sobie z tego sprawę, był ks. Józef Tischner. Jak sam siebie określał: po pierwsze człowiek, po drugie filozof, po trzecie ksiądz². Kolejność ta była nieprzypadkowa. W pierwszym bowiem momencie należy odczuć całym sobą wagę człowieczeństwa (to może zrobić tylko człowiek). Dalej należy dokonać nad nim krytycznego namysłu (to zadanie filozofów). I wreszcie ideę człowieczeństwa należy głosić i upowszechniać, a przez nią edukować społeczeństwo. Wskazywać na wartości i zagrożenia. Uczyć dyscypliny i odpowiedzialności. Z tego zadania ks. prof. Tischner wywiązywał się wzorowo, głosząc kazania, a potem spisując i upowszechniając swe myśli, nadając im kształt raczej braterskiego pouczenia, ze szczególnym wskazaniem na rolę i miejsce człowieka we współczesnym świecie, niż katechezy. Odezwy Tischnera były, i są nadal, ważne i odważne ${ }^{3}$. Nie godzą się

${ }^{1}$ Szerzej na ten temat Przemysław Zientkowski, ,Współczesne herezje praw człowieka”, w: Pogranicza. Historia - socjologia - teologia, red. Janusz Chyła, Krzysztof Krzemiński, Przemysław Zientkowski (Łeba: Instytut Balticum, 2014), 77-91.

2 Podaję za Karolem Tarnowskim: ,Józef Tischner - niezastąpiony filozof nadziei”. Wykład wygłoszony w ramach cyklu spotkań Poniedziałki z Tischnerem 20 października 2014 r., http://www.tischner.org.pl/karol-tarnowski/tischner-niezastapiony-filozof-nadziei [dostęp: 15.05.2018].

3 Zwłaszcza teksty (fragmenty Etyki solidarności) publikowane w Tygodniku Powszechnym od listopada 1980 do marca 1981 roku. 
na byle jaki kompromis, ale też wprost odnoszą się do pytań o sens i wartość każdego ludzkiego życia ${ }^{4}$. Życia każdej pojedynczej osoby oraz życia zbiorowości - i nie jest tu rzeczą najistotniejszą, czy myślimy o grupie społecznej, wspólnocie czy narodzie - od wszystkich tych zbiorowości wymaga się solidarności.

W poniższym tekście poddaję refleksji stosunek Józefa Tischnera do idei solidarności społecznej i jej przejawów w koncepcji praw człowieka. Kwestia ta wydaje się odgrywać istotną rolę w formułowaniu się współczesnej rzeczywistości i koncepcji praw człowieka w przestrzeni intelektualnych kręgów Kościoła katolickiego. Oczywiście Tischner nie był jedynym katolickim intelektualistą, który zajmował się kwestią praw człowieka. Jednocześnie Kościół jako instytucja także wypowiadał się na ten temat w ramach sprawowania urzędu nauczycielskiego. Aby zbadać, gdzie sytuują się analizy Tischnera na tle oficjalnych wypowiedzi Kościoła, porównam fragmenty Etyki solidarności, dzieła, które jawi się jako pierwszy i bardzo istotny głos księdza Tischnera $\mathrm{w}$ temacie solidarności społecznej, z fragmentami encyklik Jana Pawła II - stojącego na czele ówczesnego Kościoła, częstokroć określanego jako papieża ,praw człowieka”.

\section{Solidarność społeczna w rozumieniu współczesnego Kościoła katolickiego}

Człowiek jest jednostką społeczną. Oznacza to, że prawdziwe szczęście i spełnienie odnajduje we współdziałaniu w grupie. Wśród wielu interpretacji socjologicznych najpełniej ideę solidarności oddaje myśl Émile’a Durkheima $^{5}$, dla którego pochwała społeczeństwa jako siły czyniącej jednostkę człowiekiem (w pełnym rozumieniu człowieczeństwa) nie funkcjonowała

${ }^{4}$ „Gdy inni strajkowali, manifestowali, kłócili się o należne im prawa... ja pisałem. Chodziło - mówił - o oczyszczenie kilku podstawowych pojęć, a zarazem pokazanie, co one znaczą w nowym kontekście. [...] Nastawiłem się na rejestrację rzeczywistości i w pewnym sensie oczywistości, którą trzeba było nazwać. Na przykład na zapisanie stwierdzenia, że kiedy praca nie ma sensu, jedynym sensownym rozwiązaniem jest strajk”. Cytat za: Wojciech Bonowicz, Tischner (Kraków: Znak, 2005), 330.

${ }^{5}$ Co prawda Durkheim był ateistą, nie był typem wojującym, ale z pewnością świadomym i zdeklarowanym. Był też skrajnym antyklerykałem. Z pewnością nie należy go zatem przedstawiać jako podstawowego punktu odniesienia w rozważaniach na temat kwestii solidarności w rozumieniu Kościoła katolickiego. Jednakże jego stanowisko jest niezwykle istotne zarówno w kontekście samego zjawiska, jak i opozycji do doktryny Kościoła katolickiego. 
wcale jako pochwała jakiegoś konkretnego społeczeństwa, ale była raczej „punktem wyjścia teorii więzi społecznej”, która brała także pod uwagę różnorodność i zmienność jej form. Durkheim nazwał ją „solidarnością” i jak twierdził, jako jedyna naprawdę istnieje ${ }^{7}$. Oddaje to słowami:

Tym, co istnieje naprawdę, są poszczególne formy solidarności: solidarność rodzinna, solidarność zawodowa, solidarność narodowa, solidarność wczorajsza, solidarność dzisiejsza itd. Każda z nich ma swój własny charakter, dlatego też uogólnienia dają w każdym przypadku tylko niepełne wytłumaczenia zjawiska, odrzucają bowiem to, co konkretne i żywe.

W oparciu o Durkheimowskie przesłanki można założyć, iż idea solidarności bezpośrednio wskazuje na istnienie drugiego człowieka, a solidarność społeczna to nic innego, jak dbanie o wspólny interes. Na gruncie praw człowieka tym interesem (nie tylko w obrębie danej grupy społecznej czy narodu, ale również w wymiarze globalnym) będzie obrona innego człowieka, który szuka wsparcia. W szerszym spojrzeniu nie będzie to jednak jedynie doraźna pomoc drugiemu, ale i identyfikowanie się z problemem, co pozwoli na analizę własnej sytuacji i być może zrozumienie, iż ludzi łączy coś więcej niż tylko więzy rodzinne i tożsamość narodowa. Bez wątpienia takim łącznikiem może być wspólnota światopoglądu, postawy moralnej czy przynależność do danej organizacji czy Kościoła.

W przypadku tego ostatniego dużą rolę w rozumieniu solidarności społecznej odgrywa katolicka nauka społeczna i nauczanie papieży, zwłaszcza Jana Pawła II, który w swoich tekstach, w kontekście praw człowieka, porusza wspomnianą problematykę prawie 100 razy. Jan Paweł II odnosił się do solidarności na wielu płaszczyznach ${ }^{8}$. Jest tam zatem i kontekst pokoju, walki z tyranią, troski o rodzinę, zagadnienia dotyczące pracy i polityki społecznej. Jest troska o wspólne dobro społeczności międzynarodowej, walka o godność i szacunek dla każdej istoty ludzkiej, walka z biedą, upomina-

6 Jerzy Szacki, Historia myśli socjologicznej (Warszawa: PWN, 2005), 382.

7 Émile Durkheim, O podziale pracy społecznej, tłum. Krzysztof Wakar (Warszawa: PWN, 1999), 87-88.

8 W myśli społecznej Kościoła prawa człowieka są bowiem obecne od czasów papieża Leona XIII. Koncepcja pojawiała się także w nauczaniach Piusa XI, Piusa XII oraz Jana XXIII. Problematyka była podnoszona w czasie Soboru Watykańskiego II, a swoje dopełnienie znalazła w nauczaniu Jana Pawła II. Patrz szerzej: Henryk Skorowski, Problematyka praw człowieka (Warszawa: Wydawnictwo UKSW, 1999), 35-80. 
nie się o sprawiedliwy porządek prawny, wolność i poszanowanie życia9 W naturalny sposób, jako że Kościół realizuje funkcję nauczycielską, wypowiedzi te przyjmują wymiar pedagogiczny ${ }^{10}$, w głównej mierze poprzez treści, które niosą, ale też poprzez sposób przekazu. Jako pouczenia głowy Kościoła na ziemi niejednokrotnie powtarzane i parafrazowane, słowa zawarte w encyklikach, adhortacjach, orędziach, przesłaniach, przemówieniach, katechezach, homiliach i rozważaniach stają się częścią codzienności społeczeństw i wspólnot rzeczywiście żyjących w Kościele, w którym solidarność nabiera realnego znaczenia ze względu na nawoływanie papieża, by roztropnie troszczyć się o dobro wspólne. Solidarność tę wyraża Jan Paweł II, używając kilku słów kluczy, które służą zarówno opisaniu problematyki, jak i jej głębszemu umiejscowieniu w nauce Kościoła w oparciu o ewangeliczną argumentację. I tak wśród encyklik autorstwa papieża Polaka odnajdujemy pojęcie solidarności społecznej odniesione do następujących kwestii: pracy, wychowania, prawdy, odpowiedzialności, wyzysku, udziału w życiu społecznym ${ }^{11}$.

Ważną i wielokrotnie podkreślaną kwestią w kontekście rozważań dotyczących ks. prof. Józefa Tischnera jest fakt jego bliskiej współpracy z papieżem Janem Pawłem II. Nie ulega wątpliwości, że początkowa relacja uczeń-mistrz stała się partnerską relacją dwóch intelektualistów zaangażowanych w problematykę jakości życia społecznego ${ }^{12}$. Nie dziwi zatem, że obraz solidarności społecznej i samych praw człowieka, zawarty w twórczości ks. prof. Józefa Tischnera, odpowiada oficjalnemu nauczaniu Kościoła. Myśl Tischnera, mimo że wyrastająca bezpośrednio z nauczania Kościoła i całkowicie mu wierna, wydaje się jednak odważniejsza. Tischner bowiem,

9 Zob. Bartłomiej Pieron, Jan Paweł II. Prawa człowieka i prawa narodów (Kraków: Wydawnictwo Uniwersytetu Papieskiego Jana Pawła II, 2017).

${ }^{10}$ Henryk Seweryniak, Święty Kościół powszedni (Warszawa: Więź, 1999), 17.

${ }^{11}$ Por. Jan Paweł II, Encykliki Ojca Świętego Jana Pawła II. Pamiątka kanonizacji (Kraków: Wydawnictwo Rafael, b.r.w.).

12 Bardzo ciekawie pisze o tym Wojciech Bonowicz: „Gdyby nie Wojtyła, to - biedny Józiu! - mówią dziś zgodnie księża, którzy pamiętają ówczesną atmosferę. Co mogło mu grozić? Cofnięcie pozwolenia na wykładanie w seminarium? Zakaz zagranicznych wyjazdów? «Zesłanie» na małą parafię gdzieś na uboczu? Trudno powiedzieć. Jedno nie ulega dla nich wątpliwości: kardynał Wojtyła stworzył w Krakowie atmosferę, w której możliwe było otwarte, niezależne myślenie. [...] Ale ufał Józkowi. Jak komuś zaufał, to zaufał. Być może Wojtyła lepiej niż inni rozumiał najgłębsze racje, jakie stały za krytyką podjętą przez Tischnera" [Bonowicz, Tischner, 252]. 
robiąc krok naprzód, nie boi się zadawać pytań, na które Kościół nie zawsze chętnie odpowiada.

Poprzez porównanie wybranych zagadnień dotyczących solidarności społecznej i praw człowieka zawartych w oficjalnym nauczaniu Kościoła oraz tych samych zagadnień zawartych w Tischnerowskiej Etyce solidarności spróbujmy znaleźć odpowiedź na pytanie: jaki obraz owej solidarności wyłania się z pracy Tischnera oraz w jakim zakresie na gruncie praw człowieka jest on zgodny z nauczaniem Kościoła? Wydaje się, że za punkt wyjścia oficjalnego nauczania Kościoła przyjąć można encykliki Jana Pawła II to głos Kościoła, którego Józef Tischner doświadczał, który znał i który, jako kapłan i katolicki intelektualista, współtworzył.

Dla łatwiejszego zobrazowania przenikających się tematów, w poniższej tabeli zestawiono ze sobą odwołania do solidarności społecznej autorstwa Jana Pawła II oraz ks. prof. Józefa Tischnera. Poniższe odwołania u obu duchownych są nominalnie tożsame lub bardzo podobne. Jednak rozwiązania zaproponowane przez księdza Tischnera są bardziej otwarte na zastaną rzeczywistość, a tym samym odważniejsze.

Tabela 1. Podstawowe kategorie w myśli Józefa Tischnera oraz w nauczaniu Jana Pawła II

\begin{tabular}{|c|c|}
\hline $\begin{array}{c}\text { Jan Pawel II } \\
\text { encykliki }\end{array}$ & $\begin{array}{c}\text { Ks. prof. Józef Tischner } \\
\text { Etyka solidarności }\end{array}$ \\
\hline praca & praca \\
\hline wychowanie & dialog, wychowanie \\
\hline prawda & iluzja \\
\hline odpowiedzialność & solidarność sumień \\
\hline wyzysk & wyzysk \\
\hline udział w życiu społecznym & demokracja, władanie \\
\hline
\end{tabular}

\section{Praca}

W encyklice Laborem exercens Jan Paweł II porusza kwestię solidarności ludzi pracy, wskazując, że choć podmiot pracy jest wciąż ten sam człowiek, zmienia się jednak i różnicuje przedmiot pracy. Zatem jeśli przez pryzmat podmiotu praca ta wciąż jest jedna i ta sama, to jednak przez wzgląd 
na nowe odmiany pracy ludzkiej mogą się jednak pojawić „nieprawidłowości, które ze względów etyczno-społecznych mogą być groźne”. Celem przeciwstawienia się tym zagrożeniom należy wspólnie dążyć do opanowania zjawiska. Sam papież oddaje to słowami:

Właśnie przecież ze względu na taką nieprawidłowość o wielkim zasięgu zrodziła się w wieku ubiegłym tak zwana kwestia robotnicza [...] Kwestia ta - razem z problemami, które się z nią łączą - stała się źródłem słusznej reakcji społecznej, wyzwoliła wielki zryw solidarności pomiędzy ludźmi pracy, a przede wszystkim pomiędzy pracownikami przemysłu. To wezwanie do solidarności i wspólnego działania skierowane do ludzi pracy - przede wszystkim wycinkowej, monotonnej pracy w zakładach przemysłowych, która ograniczała osobowość ludzką na rzecz panującej nad nią maszyny - posiadało swoją doniosłą wartość i wymowę z punktu widzenia etyki społecznej. Była to reakcja przeciw degradacji człowieka jako podmiotu pracy, połączonej z niesłychanym wyzyskiem w dziedzinie zarobków, warunków pracy i troski o osobę pracownika, która połączyła świat robotniczy we wspólnocie wielkiej solidarności ${ }^{13}$.

I dalej zauważa: „Od tego czasu solidarność ludzi pracy oraz pełniejsze i bardziej odpowiedzialne uświadomienie sobie praw robotników ze strony innych dokonało w wielu wypadkach głębokich przemian" ${ }^{\prime 14}$. Podsumowaniem tych myśli jest stwierdzenie, że owe fronty solidarności w dziedzinie ludzkiej pracy nie mogą zamykać się na dialog i współpracę z innymi, może się bowiem zdarzyć tak, że będą one potrzebne w takich warunkach i w takich warstwach społecznych, które dawniej nie były nimi objęte, wszak ludzka praca nieustannie się zmienia.

Nie inaczej widzi i rozumie sens pracy Józef Tischner, pisząc, że idea solidarności jest nierozerwalnie powiązana z rzeczywistością ludzi pracy. „Solidarność okazuje się wspólnotą ludzi pracy, zmierzających wspólnie do tego, aby uwolnić ludzką pracę od ciężarów i cierpień, których przyczyną jest drugi człowiek"15. To bardzo istotne spostrzeżenie, które akceptuje, ale natychmiast też rozwija Tischner, dając jasną odpowiedź, w jaki sposób na gruncie moralności uporządkować owe wzajemne dokładanie sobie cierpień i ciężarów. Aby jednak tego dokonać, stara się Tischner bezpośrednio odpo-

\footnotetext{
13 Jan Paweł II, „Laborem exercens”, nr 8, w: Jan Paweł II, Encykliki, 100.

14 Tamże.

15 Józef Tischner, Etyka solidarności (Kraków: Znak, 2015), 25.
} 
wiedzieć, czym jest praca, uchwycić jej sens. Proponowana odpowiedź zdaje się zaskakiwać: ,,praca jest szczególną formą rozmowy człowieka z drugim człowiekiem, służącej podtrzymywaniu i rozwojowi ludzkiego życia" ${ }^{16}$. Po uściśleniu jednak Tischner rzuca nowe światło na sprawę, pisząc, że ów specyficzny dialog, dialog pracy nie polega jedynie na wymianie słów (choć te też są ważne). Jednakże przedmiotem wymiany ludzi pracy są ich wytwory. Wytwory, tworzone w czasie i w konkretnych rzeczywistościach, które sprawiają, że owa „rozmowa” nabiera szerokiego znaczenia, a każdy, kto w nią wchodzi, włącza się w dyskurs, który trwał przed nim i będzie trwał po nim. „Dziś rolnik rzuca ziarno w ziemię, którą karczowali jego pradziadowie, kosi zboże kosą lub maszyną, którą zrobiono mu gdzieś w fabryce, zebrany plon wiezie do młyna, gdzie ktoś sporządzi mąkę, mąka trafi do piekarni, gdzie narodzi się chleb - pokarm służący życiu"17. Tischner twierdzi, że rozmowa pracy służy podstawowemu celowi - służy życiu. Nadaje tym samym pracy wartość równą wartości życia. Nie jest to oczywiście wartość najwyższa, jednakże bez wątpienia podstawowa ${ }^{18}$. Cała zatem praca: „służy życiu, gdy podtrzymuje życie i zapewnia jego rozwój (praca rolnika, lekarza, budowniczego domu itp.) bądź nadaje życiu głębszy sens (np. praca artysty, filozofa, kapłana)"'19.

Zestawiając te myśli, można mieć nieodparte wrażenie, że mimo iż Tischner znał i akceptował stanowisko Kościoła, wydawało mu się ono zbyt powierzchowne. Zadziwiające, w jaki sposób pogłębia i uduchowia myśl na temat pracy, jako kapłan rozumiejąc przecież, iż jest ona nakazana przez Boga, ale interpretując ją w zupełnie nowym kontekście w zastanej rzeczywistości.

\section{Wychowanie}

Zawarta w encyklice Sollicitudo rei socialis problematyka wychowania w kontekście praw człowieka i solidarności społecznej szczególnie mocno wybrzmiewa w następujących słowach:

16 Tamże.

17 Tamże, 26.

18 Ciekawie na ten temat: Jarosław Legięć, Człowiek w filozofii pracy Józefa Tischnera (Kraków: Dehon, 2012), 141-152.

19 Tischner, Etyka, 27. 
Ukazany wyżej obraz byłby niepełny, gdyby do ekonomicznych i społecznych wskaźników niedorozwoju nie doszły inne, równie negatywne, co więcej, bardziej jeszcze niepokojące, poczynając od dziedziny kulturowej. Są to analfabetyzm, trudności czy niemożność osiągnięcia poziomu wyższego wykształcenia, niezdolność do uczestnictwa w budowaniu własnego narodu, różne formy wyzysku, czy ucisku ekonomicznego, społecznego, politycznego, a także religijnego osoby ludzkiej i jej praw, wszelkiego rodzaju dyskryminacje, zwłaszcza ta najbardziej odrażająca, oparta na różnicy rasowej. Jeśli którąś z tych plag odczuwa się w strefie najbardziej rozwiniętej Północy, to niewątpliwie występują one częściej, są trwalsze i trudniejsze do wykorzenienia w krajach słabiej rozwiniętych ${ }^{20}$.

W innym miejscu papież wprost wypomina, iż niedorozwój, którego jesteśmy świadkami i uczestnikami, jest niedorozwojem nie tyle ekonomicznym, ile raczej kulturowym, politycznym i ,po prostu ludzkim”. Konieczna jest zatem praca u podstaw - wychowanie, by zmieniać mentalność i budować świadomość. Konkluduje to słowami: „Równocześnie, w świecie podzielonym i gnębionym różnego rodzaju konfliktami, torują sobie drogę przekonanie o radykalnej współzależności i w konsekwencji, potrzeba takiej solidarności, która by ją podejmowała i przenosiła na płaszczyznę moralną. Dzisiaj chyba bardziej niż w przeszłości ludzie zdają sobie sprawę z łączącego ich wspólnego przeznaczenia, aby budować razem, jeśli chce się uniknąć zagłady wszystkich"21.

Spojrzenie Tischnera na wychowanie ponownie jest próbą dopowiedzenia i zgłębienia tego, co w nauczaniu Kościoła jest ważne, ale wydaje się tylko surową diagnozą. Tischner, dostrzegając problem, próbuje w taki sposób formułować swoje spostrzeżenia, by stały się od razu receptą i podpowiedzią, w jaki sposób należy go rozwikłać. Wychowanie widzi zatem jako pracę z człowiekiem i nad człowiekiem - z tym, który dojrzewa - kluczową rolę w tym procesie odgrywa nadzieja. „Podejmując refleksję nad wychowaniem, wkraczamy w świat nadziei dojrzewającego człowieka. Trzeba powiedzieć tak: wychowują jedynie ci, którzy mają nadzieję. Do tego należy dodać: wychowują, kształtując nadzieję wychowanków. Wychowanie jest pracą około ducha - pracą według nadziei. Dopiero za nadzieją przychodzi miłość, buduje się wiara, kształtuje odpowiedni zmysł rzeczywistości.

\footnotetext{
20 Jan Paweł II, „Sollicitudo rei socialis”, nr 15, w: Jan Paweł II, Encykliki, 285.

21 Tamże, nr 26, 294.
} 
Dlatego kluczową zasadą wychowania jest zasada wierności"22. To, co od razu w nauczaniu Kościoła dostrzega i transponuje do siebie Tischner, to owo „budowanie razem”23. Nie postrzega go jednak jako koncentrowanie się wychowawcy na zaspokajaniu osobistych nadziei wychowanka ${ }^{24}$ lub przeciwnie jego permanentnemu piętnowaniu. Takie wychowanie - „budowanie razem" - również opiera się na dialogu, a więc jak rozumie to filozof, zdolności spojrzenia z perspektywy drugiego człowieka. I nie chodzi tu jedynie o współczucie, a raczej o uznanie, że druga osoba ze swego punktu widzenia zawsze ma trochę racji. Oto odpowiedź na nasze uczestnictwo w tym prostym, ludzkim niedorozwoju, który w interpretacji Tischnera jawi się jako niedorozwój ducha.

\section{Prawda}

Kolejnym kluczem do rozumienia Tischnerowskiej idei solidarności społecznej w oparciu o nauczanie Kościoła jest poszukiwanie prawdy w człowieku. Prawdy, na której można budować prawa człowieka. W encyklice Sollicitudo rei socialis Jan Paweł II pisze:

Zarówno ludy, jak osoby indywidualne winny cieszyć się podstawową równością, na której opiera się na przykład Karta Organizacji Narodów Zjednoczonych: równością, która jest podstawą prawa uczestniczenia wszystkich w procesie pełnego rozwoju. Aby rozwój był pełny, winien urzeczywistniać się w ramach solidarności i wolności, bez poświęcania pod jakimkolwiek pozorem jednej czy drugiej. Moralny charakter rozwoju i działanie na jego korzyść uwidacznia się w pełni wówczas, gdy należycie przestrzegane są wszystkie wymogi płynące z porządku prawdy i dobra właściwego istocie ludzkiej ${ }^{25}$.

${ }^{22}$ Tischner, Etyka, 89.

23 „Tam gdzie brakuje owego «razem», powstaje iluzja wierności. [...] Wychowanek płynie na jednej łodzi, a wychowawca na drugiej. Gdy wychowanek zaczyna tonąć, wychowawca rzuca mu dobre rady". Tischner, Etyka, 92.

${ }^{24}$ „Wychowawca popełnia błąd, gdy koncentruje się na osobistej nadziei wychowanka jako sprawie, która jemu podlega. Chce on nie tylko budzić ze snu, ale także prowadzić za ręce przebudzonych. Usiłuje rozstrzygać to, co powinien rozstrzygać sam wychowanek. [...] W sprawach dla wychowanka najważniejszych, bo najbardziej osobistych, wychowanek musi mieć przestrzeń wolnego wyboru". Tischner, Etyka, 90.

25 Jan Paweł II, „Sollicitudo rei socialis”, nr 33, 303. 
Ta prawda i dobro uwypuklone zostają też w myśli Józefa Tischnera, gdy pisze o zagrożeniach człowieka wypływających z iluzji, a więc ,zamaskowania prawdy”: „Są iluzje religijne, filozoficzne, ideologiczne, rasowe, iluzje indywidualne i społeczne. Bardzo trudno jest walczyć z iluzjami, chodź szkody wynikające $\mathrm{z}$ nich są ogromne. Walka ta jest zadaniem nauki, nauka bowiem ze swej natury dąży do poznania prawdy"26. Wszelkie iluzje dotyczące praw człowieka i solidarności społecznej rodzą się, zgodnie z Tischnerowskim modelem, nie tyle $\mathrm{z}$ niewłaściwej interpretacji, ile $\mathrm{z}$ używania nieodpowiednich narzędzi interpretacji. Jak sam pisze: „Wydaje się, że źródłem podstawowym iluzji był metafizyczny styl myślenia o życiu społecznym. Wszelkie propozycje przemian dokonywały się w ramach tego stylu. Idzie zaś o to, by ów styl w całości odrzucić. Właściwym sposobem myślenia o życiu społecznym jest etyka. Metafizyka ma inne troski ${ }^{27}$ ”.

\section{Odpowiedzialność}

Nie mniej ważne kwestie dotykające solidarności społecznej, znajdujące się i w oficjalnym nauczaniu Kościoła i w pismach ks. prof. Józefa Tischnera, dotyczą bezpośrednio odpowiedzialności. Papież Jan Paweł II mówi o niej między innymi w encyklice Sollicitudo rei socialis.

Praktykowanie solidarności wewnątrz każdego społeczeństwa posiada wartość wtedy, gdy jego członkowie uznają się wzajemnie za osoby. Ci, którzy posiadają większe znaczenie, dysponując większymi zasobami dóbr i usług, winni poczuwać się do odpowiedzialności za słabszych i być gotowi do dzielenia się $\mathrm{z}$ innymi tym, co posiadają. Słabsi ze swej strony, postępując w tym samym duchu solidarności, nie powinni przyjmować postawy czysto biernej lub niszczącej tkankę społeczną, ale dopominając się o swoje słuszne prawa, winni również dawać swój należny wkład $\mathrm{w}$ dobro wspólne. [...] Pozytywnymi znakami we współczesnym świecie są: rosnąca świadomość solidarności pomiędzy ubogimi, ich działania na rzecz wzajemnej pomocy, wystąpienia publiczne na arenie społecznej, gdzie bez uciekania się do przemocy przedstawiają własne potrzeby i własne prawa wobec nieskuteczności działania czy korupcji władz publicznych ${ }^{28}$.

\footnotetext{
26 Tischner, Etyka, 40.

27 Tamże.

28 Jan Paweł II, „Sollicitudo rei socialis”, nr 39, 308.
} 
Co niezwykle istotne w kontekście poszanowania wspólnych interesów, Kościół widzi siebie jako współuczestnika życia społecznego stojącego na straży dobra wszystkich grup społecznych w ramach dobra wspólnego. To samo kryterium, jak wskazuje Jan Paweł II, odnosi się też (przez analogię) do stosunków międzynarodowych, w których współzależność, a niekiedy nawet podległość, winna przekształcać się w solidarność opartą na zasadzie głoszącej, że dobra stworzone są dla wszystkich. Podkreślając rolę odpowiedzialności za słabszych i ponownie, akcentując sprawiedliwy podział dóbr w duchu społecznej solidarności, mówi: „ludzie odpowiedzialni za narody i za instytucje międzynarodowe, którzy w swoich planach powinni uwzględniać w pierwszym rzędzie prawdziwy wymiar ludzki, nie mogą zapominać o dawaniu pierwszeństwa zjawisku rosnącego ubóstwa"229.

Tischner widzi to niemal identycznie: ,solidarności nie potrzeba narzucać człowiekowi z zewnątrz, przy użyciu przemocy. Ta cnota rodzi się sama, spontanicznie, z serca. [...] Cnota solidarności jest wyrazem dobrej woli człowieka. W gruncie rzeczy wszyscy jesteśmy solidarni, bo wszyscy jesteśmy w głębi naszych dusz ludźmi dobrej woli. Solidarność rodzi się z dobrej woli i budzi w ludziach dobrą wolę" ${ }^{30}$. Solidarność ta jest wyrazem odpowiedzialności oraz tego, o co tak naprawdę każdemu człowiekowi chodzi ${ }^{31}$.

\section{Wyzysk}

Mówiąc o kategorii wyzysku, Jan Paweł II podpiera się autorytetem swoich wielkich poprzedników, zwłaszcza papieża Leona XIII, wprost przedstawiając jego wykładnię: „Papież potwierdza elementarną zasadę każdej zdrowej organizacji politycznej, to znaczy takiej, w której jednostki im bardziej są bezbronne w danym społeczeństwie, tym bardziej winny być podmiotem zainteresowania i troski innych, a zwłaszcza interwencji władzy publicznej"32. Precyzuje jednak jego myśl:

29 Tamże, nr 42, 310.

30 Tischner, Etyka, 14.

31 „Gdy nadchodzi wiosna, chodzi o to, by ugasić pożar. Nauczycielowi chodzi o to, by szkoła była naprawdę szkołą, uniwersytet uniwersytetem, książka książką. Nam wszystkim idzie o to, by prawda zawsze prawdę znaczyła, a sprawiedliwość - sprawiedliwość". Tischner, Etyka, 13.

32 Jan Paweł II, „Centesimus annus”, nr 10, w: Jan Paweł II, Encykliki, 404. 
Jeśli Leon XIII apeluje do Państwa, by zgodnie z zasadami sprawiedliwości zostały polepszone warunki życia ludzi ubogich, czyni to w słusznym przekonaniu, że zadaniem Państwa jest czuwanie nad dobrem wspólnym i troska o to, by wszystkie dziedziny życia społecznego, nie wyłączając gospodarki, przyczyniły się do urzeczywistnienia go, respektując słuszną autonomię każdej z nich. Jednakże nie znaczy to, że zdaniem Papieża wszystkie rozwiązania kwestii społecznej winny pochodzić od Państwa. Przeciwnie, podkreśla on niejednokrotnie konieczność ograniczenia interwencji Państwa oraz jego charakter instrumentalny, jako że jednostka, rodzina i społeczeństwo są w stosunku do niego wcześniejsze, Państwo zaś istnieje po to, by chronić ich prawa, bynajmniej zaś nie po to, by je thumić3 ${ }^{33}$.

Nakreśla w ten sposób służebną rolę Państwa wobec obywateli, wskazując bardzo istotny fakt, iż Państwo jako takie nie jest w żadnym razie receptą na prześladowania międzyludzkie - przede wszystkim na wyzysk, wykorzystywanie gorszej pozycji i sytuacji materialnej jednych do osiągnięcia zaplanowanych celów i korzyści przez drugich. W pełni oddaje to słowami:

Społeczeństwo i Państwo winny ponadto gwarantować taki poziom zarobków, by wystarczały one na utrzymanie pracownika i jego rodziny, a także pozwoliły na gromadzenie pewnych oszczędności. Należy zatem dokładać starań, by doskonalić umiejętności i uzdolnienia pracowników i w ten sposób czynić ich pracę coraz lepszą i bardziej wydajną; ale potrzeba też nieustannej czujności i odpowiednich praw, by wyeliminować haniebne zjawiska wyzysku, przede wszystkim względem pracowników najsłabszych, imigrantów czy żyjących na marginesie społecznym. Niezmiernie ważna $w$ tej dziedzinie jest rola związków zawodowych, które zawierają kontrakty, ustalają dolną granicę zarobków i warunki pracy ${ }^{34}$.

I dalej w tym duchu pisał:

Do osiągnięcia tych celów Państwo winno się przyczyniać zarówno bezpośrednio, jak i pośrednio. Pośrednio i zgodnie z zasadą pomocniczości stwarzają warunki sprzyjające swobodnej działalności gospodarczej, która mogłaby

\footnotetext{
33 Tamże, nr 11, 405.

34 Tamże, nr 15, 410.
} 
zaoferować wiele miejsc pracy i źródeł zamożności. Bezpośrednio i zgodnie $\mathrm{z}$ zasadą solidarności, ustalając $\mathrm{w}$ obronie słabszego pewne ograniczenia autonomii tych, którzy ustalają warunki pracy, a w każdym przypadku zapewniając minimum środków utrzymania pracownikowi i bezrobotnemu ${ }^{35}$.

Drugim czynnikiem kryzysu jest niewątpliwie niesprawność systemu gospodarczego, której nie należy rozpatrywać jedynie jako problemu technicznego, ale raczej należy widzieć w tym następstwo pogwałcenia praw człowieka do inicjatywy, do własności i do wolności w dziedzinie ekonomicznej ${ }^{36}$.

Problem zauważył również ks. Józef Tischner. Wśród najczęściej poruszanych tematów w Etyce solidarności pojawia się kwestia wyzysku. Problematyka ta przewija się nieustannie, przyjmując różne formy znaczeniowe. Doczekała się jednak całościowego opracowania w jednym z akapitów. Pisze w nim Józef Tischner:

Podobnie jak kłamstwo jest chorobą mowy, tak wyzysk jest chorobą pracy. Co to jest wyzysk? Żadna teoria wyzysku, jaką znamy, nie jest zadawalająca. Jedne z nich są zbyt mocno związane z ekonomią polityczną, ale zbyt luźno z etyką, inne nawiązują wprawdzie do etyki, ale czynią to w sposób tak abstrakcyjny, że nie przekraczają progów wieloznaczności. Teorie nie nadążają za życiem. Prawdopodobnie wraz z przemianami społecznymi i gospodarczymi, jakim podlega praca społeczna, zmienia się również charakter wyzysku³ ${ }^{37}$.

W miejscu tym filozof próbuje nakreślić istotę wyzysku - widząc go przede wszystkim w podwójnej relacji wertykalnej. Pomiędzy państwem a pracownikiem oraz pomiędzy tym pracownikiem a konkretnym pracodawcą. To, co najbardziej interesujące $u$ Tischnera, to jego ujęcie tematu na gruncie etyki. Pomimo ukazanej i opisanej wertykalnej relacji tak naprawdę konkluzja jest oczywista: zjawisko wyzysku ma zawsze charakter horyzontalny - pomiędzy jednostkami, konkretnymi ludźmi. Gdzie objawia się brak dialogu i porozumienia. Sam Tischner pisze: „Pękło naturalne porozumienie między nimi. Podstawowy projekt pracy poszedł w swoją stronę, a praca konkretna w swoją. Umowa o pracę nie rodzi wzajemności. Człowieka dzieli od czło-

\footnotetext{
35 Tamże, 411.

36 Tamże, nr 24, 416.

37 Tischner, Etyka, 31.
} 
wieka jakaś niepojęta ciemność. Powtarza się wydarzenie wieży Babel, tyle, że na poziomie pracy"38.

\section{Udział w życiu społecznym}

Ostatnią kwestią dotyczącą solidarności społecznej, która wybrzmiewa zarówno w encyklikach Jana Pawła II, jak i w Etyce solidarności Tischnera, jest udział w życiu społecznym. Karol Wojtyła wprost pisze o nim w kategorii obowiązku, którego ostatecznym celem jest ochrona praw człowieka:

Solidarność, rozumiana jako mocna i trwała wola zaangażowania się na rzecz dobra wspólnego, musi się urzeczywistniać także poprzez różne formy udziału w życiu społecznym i politycznym. Tak więc służba Ewangelii życia polega również na tym, że rodziny, głównie przez zrzeszanie się w odpowiednich organizacjach, starają się oddziaływać na prawodawstwo i na instytucje państwowe, aby w żaden sposób nie naruszały one prawa do życia od poczęcia do naturalnej śmierci, ale chroniły je i umacniały ${ }^{39}$.

Tischner widzi to jednak trochę inaczej, kiedy we fragmencie zatytułowanym „Demokracja” przedstawia swój punkt widzenia: „Nie wszystko musi być zorganizowane. Nie wszystko może być zorganizowane. Człowiek musi mieć jakieś pole wolności i swobody. [...] Poprzez wolność przejawia się bogactwo osoby ludzkiej, którego nie można ograniczyć żadną funkcją" ${ }^{40}$. Brak ograniczeń znajdzie człowiek dopiero w momencie, kiedy stając w prawdzie, uświadomi sobie, jakie są jego rola i miejsce w społeczeństwie:

Wszak nie chodzi w nim tylko o to, by się dowiedzieć, czy władza naprawdę jest władzą, ale o to, czym ja jestem jako członek pewnej wspólnoty. Pytając o władzę, pytam o siebie. Polityka okazuje się istotnym elementem mej samowiedzy. Można więc i tak powiedzieć: chcąc zrozumieć siebie, muszę znaleźć odpowiedź na pytanie, komu jestem poddany, w jakiej mierze i dlaczego. Jest to zwykłe prawo człowieka ${ }^{41}$.

\footnotetext{
38 Tamże, 34.

39 Jan Paweł II, „Evangelium vitae”, nr 93, w: Jan Paweł II, Encykliki, 626-627.

40 Tischner, Etyka, 60.

41 Tamże, 76.
} 


\section{Zakończenie}

Nie ulega wątpliwości, że wykazane w tabeli odwołania do solidarności społecznej zarówno w oficjalnym nauczaniu Kościoła, jak i u ks. Józefa Tischnera są tożsame. Wyrastają bowiem z tych samych przesłanek i zbudowane zostały na tych samych wartościach. Myśl ks. prof. Tischnera daleko bardziej wykracza jednak poza sztywne ramy ostrożnego w formułowaniu sądów Kościoła. Kwestia ta może dziwić, zwłaszcza w kontekście pozycji Józefa Tischnera w Kościele. Był bowiem jego członkiem, był katolickim księdzem i jednocześnie wykładowcą na katolickich uczelniach. Cieszył się ogromnym zaufaniem i wręcz przyjaźnią papieża Jana Pawła II. Czy zatem możliwe było, by nadużywając tego zaufania, podważał oficjalne magisterium Kościoła? To raczej mało prawdopodobne. Bardziej realna wydaje się kwestia, jakoby Tischner odgrywał rolę swoistego eksploratora, który bardzo ostrożnie poruszał się po polach współcześnie przez Kościół niezgłębionych $^{42}$. Był badaczem, którego najważniejszym zadaniem było odkrycie, co jest zgodne z nauką Kościoła, co przeczy Ewangelii, a co mogłoby i powinno zostać przez Kościół przyjęte i zaakceptowane. Działalność ks. Józefa Tischnera była o tyle skomplikowana, iż w środowiskach laickich był traktowany jako zbyt blisko związany z hierarchią Kościelną, a w środowisku Kościoła przez wielu był uznawany jako osoba zbyt liberalna, a dla części niegodna bycia kapłanem. W obu środowiskach nie kwestionowano jednak jego wyjątkowej sprawności intelektualnej i niezależności myślenia. Doświadczenie pokazuje, że rola, którą odgrywał Tischner, mogła być dla niego mało komfortowa. Reprezentował on bowiem Kościół otwarty, który nie lęka się wchodzenia w dialog z każdym, nawet z tymi, którzy są wobec religii niechętnie nastawieni ${ }^{43}$. Otwartość ta mogła $\mathrm{z}$ jednej strony być nadużywana przez laickich rozmówców Tischnera, z drugiej - powodować krytykę ze strony przedstawicieli Kościoła bardziej ufającego tradycji i mniej otwartego się na nowe rozwiązania. $Z$ całą pewnością postawę taką akceptował Jan Paweł II, którego śmiało możemy nazwać „papieżem dialogu”. Zdawał on

${ }^{42}$ Choć od czasu encykliki Aeterni Patris Leona XIII (tj. od 4 sierpnia 1879 roku) aż do XXI wieku oficjalną filozofią w Kościele katolickim był, a w wielu przypadkach wciąż jest, tomizm, to pozostawia się czasem na katedrach wybitne jednostki, które eksplorują pola, na których Kościół mógłby „popłynąć”. Mam na myśli Bocheńskiego (nurt analityczny) i Tischnera (fenomenologa). Tezę uprawdopodobnił Heller (fizyka teoretyczna).

43 Również dziś w polskim Kościele są duchowni, którzy odgrywają podobną rolę. 
sobie bowiem sprawę z pozycji Tischnera w Polsce i z faktu, że gdy sam jako młodszy o całe pokolenie studiował we Włoszech tomizm, w tym samym czasie do PRL-u, w którym na co dzień funkcjonował Tischner, przesiąkały różne nurty i ideologie: od fenomenologii po egzystencjalizm, od filozofii strukturalnej po personalizm, od filozofii języka po filozofię spotkania. Wszystko to pozwoliło szybciej zobaczyć i zorientować się Tischnerowi, jakie są tak naprawdę nastroje na Zachodzie i gdzie w tym jest Polska. Wojtyła jako kościelny hierarcha zawsze bowiem patrzał z innej perspektywy. Natomiast u obu, a zatem i w nauce Kościoła, i u Tischnera, kontekst solidarności społecznej zakorzeniony jest w etyce ducha. Zatem i katolicka nauka społeczna, i Tischnerowska solidarność społeczna wyrastają z ducha etyki i jako takie dopiero rzutują na całokształt człowieka. Jak sam bowiem konkluduje Tischner: „Trzeba powiększyć duszę. «O ile powiększycie i polepszycie duszę waszą, o tyle polepszycie prawa wasze i powiększycie granice wasze»"44.

\section{The Idea of Social Solidarity as a Manifestation of Basic Human Rights in Józef Tischner's Thought (Summary)}

The article is devoted to the theory of social solidarity and its interpretation in the context of human rights. The text compares a few selected issues dealing with social solidarity and appearing in the official teaching of the Catholic Church with Józef Tischner's philosophical understanding of the problem. The author refers in his analyses to the selected encyclicals of Pope John Paul II and to Józef Tischner's famous book The Ethics of Solidarity.

Keywords: social solidarity; human rights; education; work; dialogue; the Catholic Church.

Idea solidarności społecznej jako przejaw podstawowych praw czlowieka w myśli Józefa Tischnera (Streszczenie)

Artykuł jest poświęcony teorii solidarności społecznej i jej interpretacji w kontekście idei praw człowieka. W tekście zestawiono wybrane wątki odnoszące się do

${ }^{44}$ Tischner, Etyka, 138. 
solidarności społecznej z oficjalnego nauczania Kościoła katolickiego z filozoficznym rozumieniem problemu przez Józefa Tischnera. Autor odnosi się w analizach do wybranych encyklik papieża Jana Pawła II oraz słynnej pracy Józefa Tischnera Etyka solidarności.

Słowa kluczowe: solidarność społeczna; prawa człowieka; edukacja; praca; dialog; Kościół katolicki.

\section{Bibliografia}

Bonowicz, Wojciech. Tischner. Kraków: Znak, 2005.

Durkheim, Émile. O podziale pracy społecznej, thum. Krzysztof Wakar. Warszawa: PWN, 1999.

Jan Paweł II. Encykliki Ojca Świętego Jana Pawła II. Pamiątka kanonizacji. Kraków: Rafael, b.r.w.

Legięć, Jarosław. Człowiek w filozofii pracy Józefa Tischnera. Kraków: Znak, 2012.

Pieron, Bartłomiej. Jan Pawet II. Prawa człowieka i prawa narodów. Kraków: Wydawnictwo Uniwersytetu Papieskiego Jana Pawła II, 2017.

Seweryniak, Henryk. Święty Kościót powszedni. Warszawa: PWN, 1999.

Skorowski, Henryk. Problematyka praw człowieka. Warszawa: Wydawnictwo UKSW, 1999.

Szacki, Jerzy. Historia myśli socjologicznej. Warszawa: PWN, 2005.

Tarnowski, Karol. „Józef Tischner - niezastąpiony filozof nadziei”. http://www.tischner.org.pl/karol-tarnowski/tischner-niezastapiony-filozof-nadziei [dostęp: 15.05.2018].

Tischner, Józef. Etyka solidarności. Kraków: Znak, 2015.

Zientkowski, Przemysław. „Współczesne herezje praw człowieka”. W: Pogranicza. Historia - socjologia - teologia, red. Janusz Chyła, Krzysztof Krzemiński, Przemysław Zientkowski, 77-89. Łeba: Instytut Balticum, 2014. 